\title{
Streptococcus hyovaginalis sp. nov. and Streptococcus thoraltensis sp. nov., from the Genital Tract of Sows
}

\author{
L. A. DEVRIESE, ${ }^{1 *}$ B. POT, ${ }^{2}$ P. VANDAMME, ${ }^{3,4}$ K. KERSTERS,${ }^{3}$ M. D. COLLINS, ${ }^{5}$ \\ N. ALVAREZ, ${ }^{5}$ F. HAESEBROUCK, ${ }^{1}$ AND J. HOMMEZ ${ }^{6}$ \\ Faculty of Veterinary Medicine, ${ }^{1}$ and Laboratory of Microbiology, Faculty of Sciences, ${ }^{3}$ University of Ghent, ${ }^{1}$, \\ and BCCM/LMG Culture Collection, ${ }^{2}$ Ghent, Laboratory of Medical Microbiology, University \\ Hospital, Antwerp, ${ }^{4}$ and Regional Veterinary Laboratory, Torhout, ${ }^{6}$ Belgium; \\ and BBSRC Institute of Food Research, Reading, United Kingdom ${ }^{5}$
}

Two groups of strains isolated from sows were shown to belong to new sublines in the genus Streptococcus. Based on phenotypic and phylogenetic analyses, we propose that these bacteria should be classified as two new species, Streptococcus hyovaginalis sp. nov. and Streptococcus thoraltensis sp. nov. These two species are found in the genital tract, but the capnophilic species $S$. thoraltensis may also occur in the intestinal tract of pigs. The type strain of $S$. hyovaginalis is SHV515 (= LMG 14710), and S69 (= LMG 13593) is the type strain of $S$. thoraltensis.

Virtually nothing is known about the normal or abnormal vaginal flora of sows. Streptococcus-like strains are frequently present in vaginal fluids, and a carboxyphilic biotype of Streptococcus suis (5) was found exclusively in this habitat. During a more recent investigation of the vaginal flora of sows, we isolated two groups of gram-positive coccus-shaped organisms which phenotypically did not resemble any of the previously recognized coccal species. Whole-cell protein analysis showed that the strains of the two groups were distinct from each other and from previously described species of the genus Streptococcus. 16S rRNA sequence analysis confirmed the genotypic separateness of the two groups and demonstrated that they represent two new species of the genus Streptococcus.

In the present communication we describe two new species based on a study of the two groups of strains from pigs.

\section{MATERIALS AND METHODS}

Strains. Several strains were isolated from vaginal fluids of sows (all from different Belgian farms) on Columbia blood agar (Oxoid, Basingstoke, United Kingdom). These strains were deposited in the BCCM/LMG Culture Collection of the University of Ghent as strains LMG 14843 (= SHV426), LMG 14711 (= SHV480), LMG 14712 (= SHV488), LMG $14710^{\mathrm{T}}$ (= SHV515 ${ }^{\mathrm{T}}$ ), LMG 14708 (derived from T195), LMG 14174 (derived from T195), LMG 14386 (derived from T195), LMG 14173 (= T113), LMG 14704 (= Tor474), LMG 14709 (Tor 489), LMG 14706 (= Tor505), and LMG 14707 (= Tor524). Strain LMG 14705 (= Tor351) was obtained from the liver of an aborted swine fetus, and strain LMG $13593^{\mathrm{T}}\left(=\mathrm{S} 69^{\mathrm{T}}\right)$ was obtained from the intestines of a pig.

Whole-cell protein analysis. All of the strains included in Fig. 1 were subjected to a sodium dodecyl sulfate-polyacrylamide gel electrophoresis (SDS-PAGE) analysis of whole-cell proteins. Cells were grown on MRS agar (Oxoid) in petri dishes at $37^{\circ} \mathrm{C}$ for $24 \mathrm{~h}$, inoculated from a 24-h MRS broth culture, and incubated under the same conditions. Whole-cell protein extracts were prepared as described previously (19), and SDS-PAGE was performed by using a modification (19) of the Laemmli method (15). Registration of the protein electrophoretic patterns, normalization of the densitometric traces, grouping of strains with the Pearson product moment correlation coefficient $(r)$, and unweighted average pair group cluster analysis were performed by the techniques described by Pot et al. (19) by using the software package GelCompar, version 4.0 (Applied Maths, Kortrijk, Belgium) (22).

16S rRNA gene sequencing and phylogenetic analysis. A large fragment of the 16S rRNA gene (corresponding to positions 30 to 1521 of the Escherichia coli $16 \mathrm{~S}$ rRNA gene) was amplified by PCR by using conserved primers close to the $3^{\prime}$ and 5 ' ends of the gene. The PCR products were purified with a Prep-A-Gene kit (Bio-Rad, Hercules, Calif.) according to the manufacturer's instructions and

* Corresponding author. Mailing address: Faculty of Veterinary Medicine, Salisburylaan 133, B-9820 Merelbeke, Belgium. Phone: (32) 926474 35. Fax: (32) 92647494. were directly sequenced by using a Taq DyeDeoxy terminator cycle sequencing kit (Applied Biosystems, Foster City, Calif.) and an automated DNA sequencer (model 373A; Applied Biosystems). The closest known relatives of the new isolates were determined by performing a database search with the program FASTA of the Genetics Computer Group package (4). The sequences of the closest known relatives and of other related strains were retrieved from the EMBL and Ribosomal Database Project data libraries and aligned with the newly determined sequences by using the program PILEUP (4). The resulting multiple-sequence alignment was corrected manually, and approximately 100 bases at the $5^{\prime}$ end of the rRNA gene were omitted because of alignment ambiguities. A continuous stretch of 1,330 bases was used for a distance matrix analysis. A distance matrix was calculated by using the programs PRETTY (4) and DNADIST (using the Kimura-2 correction parameter) (13). A phylogenetic tree was constructed by using the neighbor-joining method with the program NEIGHBOR (13). The stability of the groups was estimated by performing a bootstrap analysis (200 replications) with the programs DNABOOT, DNADIST, NEIGHBOR, and CONSENSE (13).

The average $\mathrm{G}+\mathrm{C}$ contents of the DNAs of strains LMG $14710^{\mathrm{T}}$ and LMG $13593^{\mathrm{T}}$ were determined by the thermal denaturation method and were calculated as described by De Ley (2).

Growth, serological reactions, resistance, and biochemical activity. Brain heart infusion medium (Biolife, Milan, Italy) and Columbia agar (Lab M, Bury, United Kingdom) supplemented with $5 \%$ bovine blood were used to determine growth characteristics on nonselective media. Motility was tested on semisolid medium containing 0.02\% Noble agar (Difco Laboratories, Detroit, Mich.). Lancefield carbohydrate antigens were tested with a Streptococcal Grouping Kit (Oxoid). Resistance to $6.5 \% \mathrm{NaCl}$ was determined in brain heart infusion medium containing $\mathrm{NaCl}$. Resistance to sodium azide was tested by inoculating organisms onto Slanetz-Bartley agar (Oxoid) and kanamycin-esculin-azide agar (Lab M), and resistance to bile was tested by inoculating organisms onto esculinbile agar (Difco). Media were incubated at $37^{\circ} \mathrm{C}$ in air supplemented with $5 \%$ $\mathrm{CO}_{2}$. Enzymatic and carbohydrate acidification tests were carried out with API 20 STREP, API 50CH, and rapid ID32 STREP galleries (BioMérieux, Marcyl'Etoile, France) at $37^{\circ} \mathrm{C}$ in air. Weak or doubtful enzymatic test results were confirmed with Rosco substrate tablets and reagents (Rosco, Taastrup, Denmark). Amylase production was tested by spot inoculating organisms onto Columbia agar without added blood, and reactions in milk were tested in litmus milk (Oxoid).

Nucleotide sequence accession numbers. The 16S rRNA sequences of strains LMG $13593^{\mathrm{T}}$ and LMG $14710^{\mathrm{T}}$ have been deposited in the GenBank database under accession no. Y09007 and Y07601, respectively.

\section{RESULTS}

Identification of isolates by SDS-PAGE of whole-cell proteins. The results of an SDS-PAGE analysis of whole-cell proteins allowed us to group all of the streptococcal strains (Fig. 1). Moreover, all of the new isolates were found to be different from the previously described species of the genus Streptococ$c u s$, as revealed by a comparison with a database of onedimensional SDS-PAGE protein patterns (18). In Fig. 1, the first cluster (cluster I) comprised strains LMG $14710^{\mathrm{T}}$, LMG 
Similarity Dendrogram

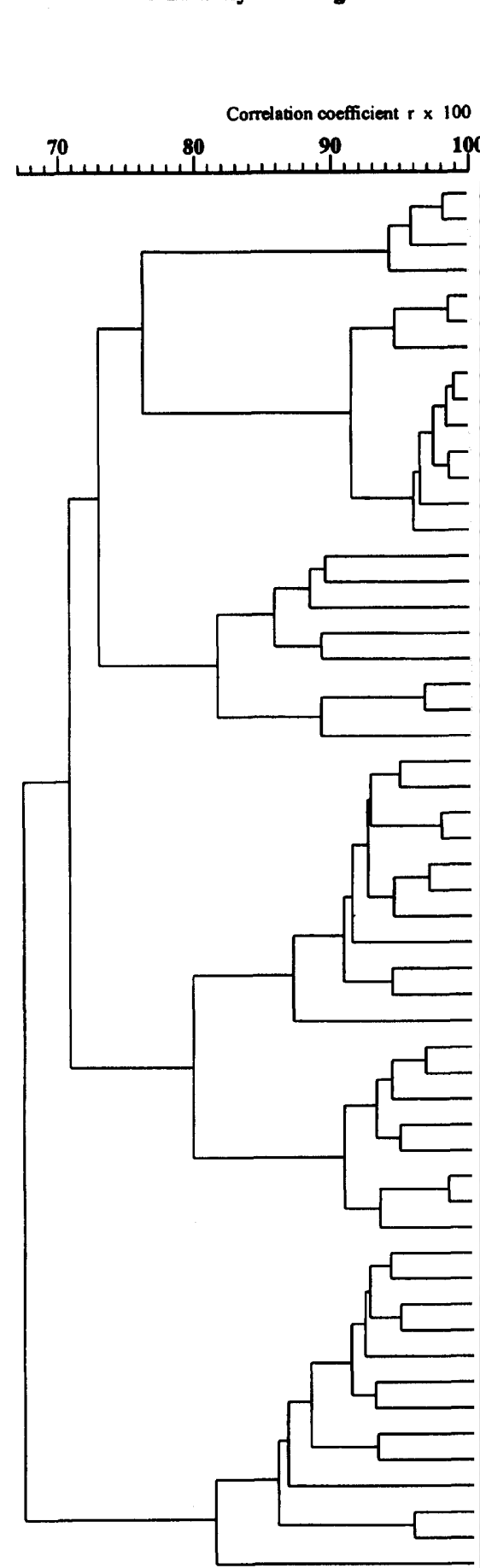

Normalised Protein Profiles

LMG number

Cluster Number

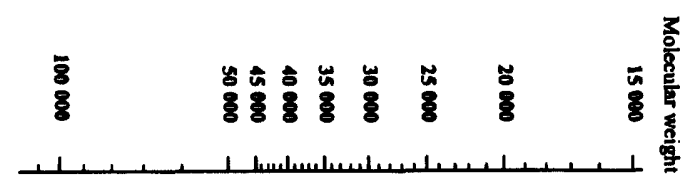

LMG 1471

LMG 14712

LMG 14710T

LMG 14843

LMG 14173

LMG 14174

LMG 14386

LMG 14704

LMG 14706

LMG 14705

LMG 14707

LMG 14708

LMG 13593T

LMG 14709

LMG 14589

LMG 14810

LMG 14591

LMG 14588

LMG 14808T

LMG 14590t1

LMG 14590t2

LMG 14811

LMG $14579 T$

LMG 14581

LMG 16885

LMG 16879

LMG 14584

LMG 14585

LMG 14583

LMG 14582

LMG 14586

LMG 14587

LMG 14479

LMG 15548

LMG 15551

LMG 15549

LMG 15550

LMG 14615

LMG 15980T

LMG 15981

LMG 15547

LMG 14184

LMG 14643

LMG 14895

LMG 14896

LMG 14644

LMG 14181

LMG 14183

LMG 14403

LMG 14644

LMG 14101

LMG 14185

LMG 14404

LMG 11742
CLUSTER I

S. hyovaginalis

\section{CLUSTER II}

S. thoraltensis

\section{CLUSTER IV}

S. hyointestinalis

CLUSTER V

S. porcinus

\section{CLUSTER VI}

S. suis

FIG. 1. On the left the mean correlation coefficients, expressed as percentages $(r \times 100)$, are represented as a dendrogram that was constructed by the unweighted average pair group method for a number of Streptococcus strains isolated from pigs. Points 10 to 325 of the 400 -point traces were used to calculate similarities between individual pairs of traces. In the center is a computer-processed printout of positions 0 (top of gel, left side of the pattern) to 360 (front of gel, right side of the pattern) of the digitized and normalized protein patterns of all of the strains compared. On the right are the strain designations (Culture Collection of the Laboratory of Microbiology, Department of Physiology, Biochemistry and Microbiology, Faculty of Sciences, University of Ghent, Ghent, Belgium), cluster numbers, and species names. The suffixes $t 1$ and $t 2$ indicate two different colony types.

14711, LMG 14712, and LMG 14843, grouping at a correlation coefficient $(r \times 100)$ of $>93.9 \%$. Cluster II was composed of 10 strains (LMG 13593' ${ }^{\mathrm{T}}$, LMG 14173, LMG 14708, LMG 14386, LMG 14174, LMG 14704, LMG 14705, LMG 14706, LMG
14707 , and LMG 14709) $(r \times 100$ of $>91.1 \%)$. Three independent subcultures of strain T195 (LMG 14708, LMG 14174, and LMG 14386) (Fig. 1) were analyzed separately, and a reproducibility value $(r \times 100)$ of $91.1 \%$ was obtained for the inde- 


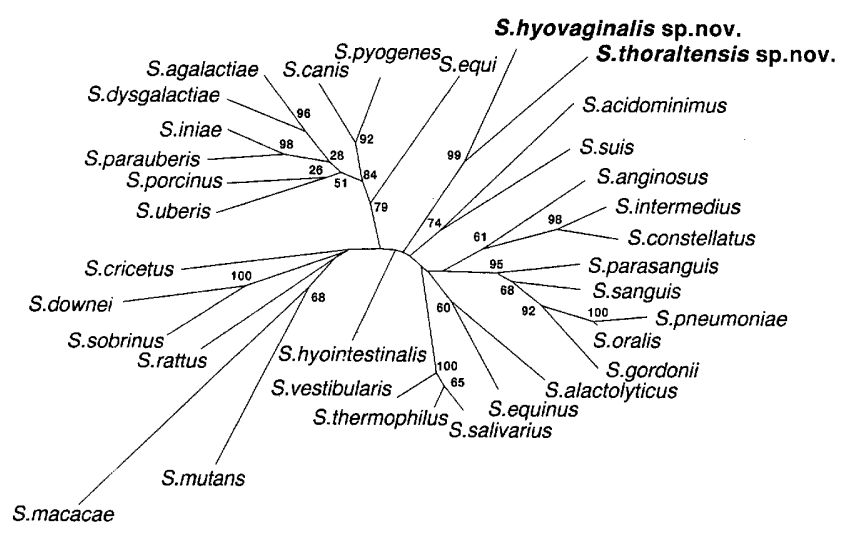

FIG. 2. Unrooted tree showing the phylogenetic positions of $S$. hyovaginalis and $S$. thoraltensis within the genus Streptococcus. The tree is based on 1,330 positions of the 16S rRNA and was constructed by using the neighbor-joining method.

pendent protein extracts analyzed on different gels. Figure 1 also shows the relationships of clusters I and II with other swine-associated species, including Streptococcus suis (cluster VI), Streptococcus hyointestinalis (cluster IV), Streptococcus porcinus (cluster V), and Streptococcus alactolyticus (cluster III). All of the species included occupied separate positions on the dendrogram.

16S rRNA gene sequence analysis. The $16 \mathrm{~S}$ rRNA genes of two representatives of each of the two new clusters were amplified by PCR and subjected to sequence analysis. Almostcomplete gene sequences were determined for strains LMG $14710^{\mathrm{T}}$ (cluster I) and LMG $13593^{\mathrm{T}}$ (cluster II). Approximately 700 nucleotides from the $5^{\prime}$ end of the rRNA, which included diagnostic variable regions $\mathrm{V} 1$ to $\mathrm{V} 3$, were determined for strains LMG 14711 (cluster I) and LMG 14174 (cluster II). Pairwise analysis showed that cluster I and II organisms were phylogenetically separate $(>4 \%$ 16S rRNA sequence divergence), but that within each cluster the two representative strains were genotypically homogeneous (i.e., they had identical sequences based on ca. 700 nucleotides). Comparative sequence searches of the EMBL and GenBank libraries revealed that the two groups of isolates from pigs were phylogenetically closely related to the genus Streptococcus. A tree depicting the phylogenetic positions of cluster I and II organisms (as exemplified by strains LMG $14710^{\mathrm{T}}$ and LMG $13593^{\mathrm{T}}$, respectively) within the genus Streptococcus is shown in Fig. 2, and representative sequence similarities are given in Table 1.

Morphology and growth characteristics. The four strains belonging to cluster I grew as long chains of gram-positive cocci which produced deposits with clear supernatants in broth media. Colonies on blood agar were regular, small (diameter, $0.5 \mathrm{~mm}$ or less), nonpigmented, translucent, and surrounded by zones of sharply demarcated alpha-hemolysis. Growth at $37^{\circ} \mathrm{C}$ was more abundant than growth at 25,30 , or $42^{\circ} \mathrm{C}$ and was slightly enhanced by incubation in a $5 \% \mathrm{CO}_{2}$-supplemented atmosphere. The strains were nonmotile. Cluster I strains were unable to grow in broth containing $6.5 \% \mathrm{NaCl}$, on esculin-bile agar, and on Slanetz-Bartley agar. Lancefield reactions were negative.

All of the cluster II strains were gram-positive cocci whose cells were arranged in short chains, pairs, or groups and were nonmotile. Colonies on blood agar incubated in the presence of $5 \% \mathrm{CO}_{2}$ were regular, not translucent, enterococcus-like but smaller (approximately $1 \mathrm{~mm}$ in diameter), and alpha-hemo- lytic. Very small pinpoint colonies were seen when the organisms were incubated in air. Growth occurred at 25 to $37^{\circ} \mathrm{C}$, but was strongly inhibited at $42^{\circ} \mathrm{C}$. Cultures in broth media produced deposits and clear supernatants. The cluster II strains grew in broth media containing $6.5 \% \mathrm{NaCl}$ after 2 days of incubation. They were relatively resistant to sodium azide and grew on Slanetz-Bartley medium when they were incubated in the presence of $5 \% \mathrm{CO}_{2}$. Triphenyltetrazolium chloride was not reduced in this selective medium. Growth was strongly inhibited on esculin-bile medium. None of the strains reacted in Lancefield agglutination tests.

Biochemical activity. The four cluster I strains reacted positively in the following tests: Voges-Proskauer; hippurate; alkaline phosphatase; leucine arylamidase (often weak); $\beta$-glucuronidase (not always positive in API 20 STREP tests); $\beta$-galactosidase; alanine phenylalanine proline arylamidase; $N$-acetyl- $\beta$-glucosaminidase; and acidification of galactose, D-glucose, D-fructose, D-mannose, mannitol, sorbitol, $N$-acetylglucosamine, salicin, cellobiose, maltose, lactose, saccharose, and trehalose.

Tests were negative with reagents for pyrrolidonyl arylamidase, $\alpha$-galactosidase, arginine dihydrolase, glycyltryptophan arylamidase, $\beta$-mannosidase, and urease. Acid was not produced from glycerol, erythritol, D- and L-arabinose, D- and L-xylose,

TABLE 1. Similarity values based on the $16 \mathrm{~S}$ rRNA sequences of $S$. hyovaginalis sp. nov., $S$. thoraltensis sp. nov., and other Streptococcus species

\begin{tabular}{|c|c|c|c|c|}
\hline \multirow[b]{2}{*}{ Species } & \multirow{2}{*}{$\begin{array}{c}\text { EMBL } \\
\text { accession } \\
\text { no. }{ }^{a}\end{array}$} & \multirow[b]{2}{*}{ Strain } & \multicolumn{2}{|c|}{$\%$ Similarity to: } \\
\hline & & & $\begin{array}{l}\text { S. hyo- } \\
\text { vaginalis }\end{array}$ & $\begin{array}{c}\text { S. thoral- } \\
\text { tensis }\end{array}$ \\
\hline Streptococcus acidominimus & X58301 & NCDO $2025^{\mathrm{T}}$ & 94.0 & 93.8 \\
\hline Streptococcus agalactiae & X59032 & NCDO $1348^{\mathrm{T}}$ & 95.5 & 93.8 \\
\hline Streptococcus alactolyticus & X58319 & NCDO $1091^{\mathrm{T}}$ & 94.4 & 94.6 \\
\hline Streptococcus anginosus & X58309 & NCDO $10713^{\mathrm{T}}$ & 93.6 & 94.3 \\
\hline Streptococcus canis & X59061 & DSM $20715^{\mathrm{T}}$ & 94.6 & 93.9 \\
\hline Streptococcus constellatus & X58310 & NCTC $11325^{\mathrm{T}}$ & 94.6 & 93.9 \\
\hline Streptococcus cricetus & X58305 & NCDO $2720^{\mathrm{T}}$ & 94.3 & 94.0 \\
\hline Streptococcus downei & X58306 & NCTC $11391^{\mathrm{T}}$ & 95.6 & 93.9 \\
\hline Streptococcus dysgalactiae & X59030 & NCDO $2023^{T}$ & 94.8 & 93.7 \\
\hline Streptococcus equi & X58314 & NCDO $2493^{T}$ & 93.8 & 94.4 \\
\hline Streptococcus equinus & X58318 & $\operatorname{NCDO} 1037^{\mathrm{T}}$ & 94.8 & 94.7 \\
\hline Streptococcus gordonii & D38483 & NCTC $7865^{\mathrm{T}}$ & 94.1 & 93.0 \\
\hline Streptococcus hyointestinalis & X58313 & DSM $20770^{\mathrm{T}}$ & 96.0 & 95.9 \\
\hline Streptococcus hyovaginalis & Y07601 & LMG $14710^{\mathrm{T}}$ & 100 & 96.4 \\
\hline Streptococcus iniae & X58316 & NCDO $2722^{\mathrm{T}}$ & 94.8 & 93.3 \\
\hline Streptococcus intermedius & X58311 & NCTC $11324^{\mathrm{T}}$ & 94.2 & 94.5 \\
\hline Streptococcus macacae & X58302 & NCTC $11558^{\mathrm{T}}$ & 91.4 & 92.0 \\
\hline Streptococcus mutans & X58303 & NCTC $10449^{T}$ & 93.6 & 93.2 \\
\hline Streptococcus oralis & X58308 & NCTC $11427^{\mathrm{T}}$ & 94.9 & 93.9 \\
\hline Streptococcus parasanguis & X53652 & $85-81^{b}$ & 95.3 & 94.9 \\
\hline Streptococcus parauberis & & NCDO $651^{b}$ & 94.2 & 93.3 \\
\hline Streptococcus pneumoniae & X58312 & NCTC $7465^{\mathrm{T}}$ & 94.3 & 93.3 \\
\hline Streptococcus porcinus & X58315 & NCDO $600^{\mathrm{T}}$ & 94.8 & 94.1 \\
\hline Streptococcus pyogenes & X59029 & $\mathrm{NCDO} 2381^{\mathrm{T}}$ & 94.6 & 94.0 \\
\hline Streptococcus rattus & X58304 & NCDO $2723^{\mathrm{T}}$ & 93.3 & 93.7 \\
\hline Streptococcus salivarius & X58320 & NCDO $1779^{\mathrm{T}}$ & 95.0 & 94.8 \\
\hline Streptococcus sanguis & X53653 & NCTC $7863^{\mathrm{T}}$ & 94.7 & 94.3 \\
\hline Streptococcus sobrinus & X58307 & DSM $20742^{T}$ & 94.8 & 94.1 \\
\hline Streptococcus suis & X59031 & NCTC $10237^{\mathrm{T}}$ & 95.3 & 94.8 \\
\hline Streptococcus thermophilus & X59028 & NCDO $573^{\mathrm{T}}$ & 95.3 & 94.9 \\
\hline Streptococcus thoraltensis & Y09007 & LMG $13595^{\mathrm{T}}$ & 96.4 & 100 \\
\hline Streptococcus uberis & & NCDO $643^{b}$ & 93.6 & 93.7 \\
\hline Streptococcus vestibularis & X58321 & NCTC $12166^{\mathrm{T}}$ & 94.9 & 94.9 \\
\hline
\end{tabular}
(23)

${ }^{a}$ The sequences of $S$. uberis and $S$. parauberis have been published previously ${ }^{b}$ Not the type strain. 
TABLE 2. Characteristics useful for differentiating $S$. hyovaginalis from $S$. hyointestinalis, $S$. alactolyticus, and $S$. suis

\begin{tabular}{lccc}
\hline \multicolumn{1}{c}{ Test } & S. hyovaginalis & $\begin{array}{c}\text { S. hyointestinalis } \\
\text { and S. alactolyticus }\end{array}$ & S. suis \\
\hline Amylase & $-^{a}$ & + & + \\
$\begin{array}{l}\beta \text {-Glucuronidase } \\
\text { Voges-Proskauer }\end{array}$ & + & - & $\mathrm{D}+$ \\
Acid produced from: & + & + & - \\
$\quad$ Ribose & + or & - & - \\
Mannitol & + & - & $\mathrm{D}-$ \\
\hline
\end{tabular}

${ }^{a}-$, negative; + , positive; $\mathrm{D}+$, more than $75 \%$ of the strains are positive; $\mathrm{D}-$, less than $25 \%$ of the strains are positive.

$\beta$-methylxyloside, L-sorbose, rhamnose, dulcitol, inositol, $\alpha$ methyl-D-mannoside, $\alpha$-methyl-D-glucoside, amygdalin, melibiose, inulin, melezitose, D-raffinose, starch, glycogen, xylitol, $\beta$ gentiobiose, D-turanose, D-lyxose, D-tagatose, D- and L-fucose, D- and L-arabitol, gluconate, 2- and 5-ketogluconate, and pullulan.

Reactions were variable in tests for ribose, $\beta$-glucosidase, and methyl- $\beta$-D-glucopyranoside.

The API 20 STREP profiles of the cluster I strains were 3-4(0)-7-2(0)-7-1-0, and the rapid ID32 STREP profiles were $0(4)-5-7-3-7-2-1-1$

All cluster II strains were positive in the following tests: Voges-Proskauer; leucine arylamidase; arginine dihydrolase; alanine phenylalanine proline arylamidase; $\beta$-glucuronidase; alkaline phosphatase (often weak); $\beta$-glucosidase; and acidification of ribose, galactose, glucose, fructose, mannose, mannitol, $\mathrm{N}$-acetylglucosamine, arbutin, salicin, cellobiose, lactose, maltose, saccharose, trehalose, $\beta$-gentiobiose, methyl- $\beta$-D-glucopyranoside, $\mathrm{L}$-arabinose, inulin, starch, and pullulan.

The cluster II strains did not react in the following tests: production of amylase as determined by the plate procedure; pyrrolidonyl arylamidase; $\beta$-mannosidase; urease; and $\mathrm{N}$-acetyl$\beta$-glucosaminidase. Acid was not produced from glycerol, erythritol, $D$-arabinose, L-xylose, adonitol, $\beta$-methyl-D-xyloside, L-sorbose, rhamnose, dulcitol, inositol, $\alpha$-methyl-D-mannoside, glycogen, xylitol, D-lyxose, D- and L-fucose, D- and L-arabitol, gluconate, 2- and 5-ketogluconate, and cyclodextrin.

Variable reactions were obtained with cluster II strains in tests for $\alpha$-galactosidase, alkaline phosphatase, glycyltryptophan arylamidase, and hippurate hydrolysis. $\beta$-Galactosidase was negative in API 20 STREP tests, while positive reactions were observed with substrate 1 of the rapid ID32 STREP system and variable reactions were observed with substrate 2 of the same system. All of the strains except one or two produced acid from sorbitol, amygdalin, melibiose, melezitose, raffinose, and D-turanose. Only three or four of the eight strains were positive in tests performed with tagatose, D-xylose, and $\alpha$-methylD-glucoside.

The API 20 STREP profiles of the strains investigated were 7(5,1)-6(4)-6-7-7(5)-7(3)-1. The rapid ID32 STREP test profiles were $7-7(1,3)-7-7-3(7)-4(0)-5-3(5,7)$.

\section{DISCUSSION}

SDS-PAGE of whole-cell proteins. In the present study, the normalized protein patterns that were obtained for a number of porcine streptococcal strains isolated mainly from vaginal fluids of sows were compared to a database containing the one-dimensional SDS-PAGE protein patterns of most previously described species of lactic acid bacteria, including the streptococci $(18,20,21)$. Identification by SDS-PAGE is known to be reliable on the species and subspecies levels $(3,10$, $14,16-18,21)$. The lack of meaningful similarity with any of the previously described streptococcal, pediococcal, lactococcal, or enterococcal species suggested that we should perform a phylogenetic analysis with 16S rRNA sequences, which confirmed the separate species positions of the two SDS-PAGE clusters.

Phylogenetic analysis. The $16 \mathrm{~S}$ rRNA gene sequence analysis unequivocally demonstrated that the two clusters of isolates from pigs were phylogenetically members of the genus Streptococcus. Within the streptococcal clade, the two clusters formed distinct sublines and exhibited specific phylogenetic affinity with each other (Fig. 2). They were peripherically associated with the pyogenic subgroup of the genus Streptococcus (1). Sequence divergence values of $>4 \%$ between cluster I and II organisms and $S$. hyointestinalis clearly demonstrated that the two new streptococci from pigs represent hitherto unknown species of the genus. The phylogenetic distinctiveness of the two pig bacteria is consistent with their separateness, as revealed by whole-cell protein analysis, and we propose that cluster I and II organisms should be designated Streptococcus hyovaginalis sp. nov. and Streptococcus thoraltensis sp. nov., respectively.

Growth and biochemical activity. S. hyovaginalis has growth characteristics which are traditionally associated with streptococci. Biochemically, this species is not very reactive, and in particular the range of carbohydrates acidified is limited. In contrast, $S$. thoraltensis is active on a wide range of substrates, and its carboxyphilic nature is a prominent characteristic. Colonies are enterococcus-like, and the strains grow slowly in broth containing $6.5 \% \mathrm{NaCl}$, react positively in the VogesProskauer test, and produce acid from ribose. These characteristics are usually associated with enterococci (8) but may be found in certain streptococcal species $(9,11)$ and species belonging to certain other genera of gram-positive cocci (12). The strains showed reaction spectra which somewhat resembled those of Streptococcus uberis and Enterococcus cecorum. S. thoraltensis can be readily differentiated from Enterococcus cecorum and $S$. uberis by its lack of acid production from L-arabinose and from Enterococcus cecorum also by its hydrolysis of arginine (Table 2). It is pertinent that whereas Enterococcus cecorum is a normal component of the porcine intestinal flora, $S$. uberis does not occur in pigs.

Phenotypic characteristics useful in differentiating $S$. hyovaginalis from the phenotypically most similar porcine streptococci, S. hyointestinalis, $S$. alactolyticus, and $S$. suis, are listed in Table 3. S. hyovaginalis differs most markedly from $S$. thoraltensis in its negative arginine, L-arabinose, inulin, and raffinose

TABLE 3. Characteristics useful for differentiating $S$. thoraltensis from other phenotypically or genotypically related porcine intestinal gram-positive cocci

\begin{tabular}{lccc}
\hline \multicolumn{1}{c}{ Test } & $\begin{array}{c}\text { S. } \text { thoral }_{\text {tensis }} \\
\text { ten }^{-}\end{array}$ & $\begin{array}{c}\text { S. hyointes- } \\
\text { tinalis }^{b}\end{array}$ & $\begin{array}{c}\text { Enterococcus } \\
\text { cecorum }^{c}\end{array}$ \\
\hline $\begin{array}{l}\text { Carboxphilic growth } \\
\text { Production of } \beta \text {-glucuronidase }\end{array}$ & + & - & + \\
$\begin{array}{l}\text { Hydrolysis of arginine } \\
\text { Acid produced from: }\end{array}$ & + & - & + \\
L-Arabinose & + & - & - \\
Ribose & + & - & - \\
Mannitol & + & - & - \\
Inulin & + & - & - or + \\
\end{tabular}

${ }^{a}$ Based on results obtained with $S$. thoraltensis strains in this study.

${ }^{b}$ Data from reference 6 .

Data from references 7 and 9. 
reactions. $S$. hyovaginalis cannot be mistaken as belonging to two other porcine streptococcal taxa, S. porcinus and the betahemolytic biotype of $S$. dysgalactiae subsp. dysgalactiae, because of its lack of beta-hemolysis and arginine dihydrolase activity.

Description of Streptococcus hyovaginalis sp. nov. Streptococcus hyovaginalis (hy.o.va.gi.na'lis. Gr. n. hys, pig; L. n. vagina, sheath, vagina; N. L. masc. adj. hyovaginalis, associated with the vagina of pigs). Cells are gram-positive, catalase-negative cocci. Strains are positive in Voges-Proskauer tests and in tests for alkaline phosphatase, alanine phenylalanine proline arylamidase, $N$-acetyl- $\beta$-glucosaminidase, and acidification of galactose, D-glucose, D-fructose, D-mannose, mannitol, $N$-acetylglucosamine, salicin, cellobiose, maltose, lactose, saccharose, and trehalose.

The type strain is SHV515; it was isolated in 1990 from the vagina of a pig and has been deposited in the BCCM/LMG Culture Collection as strain LMG 14710. Its biochemical reactions are the same as those indicated above. This strain is positive in tests for ribose and negative in methyl- $\beta$-D-glucopyranoside tests. The $\mathrm{G}+\mathrm{C}$ content of $\mathrm{LMG} 14710^{\mathrm{T}}$ is 40 mol\%.

Description of Streptococcus thoraltensis sp. nov. Streptococcus thoraltensis (thor.al.ten'sis. L. gen. n. thoraltensis, from Thoraltum, L.name of Torhout, the town where the strains were isolated). Cells are gram-positive cocci. Strains are capnophilic and are positive in Voges-Proskauer tests and tests for leucine arylamidase, alanine phenylalanine proline arylamidase, $\beta$-glucuronidase, alkaline phosphatase (often weak), $\beta$-glucoside, and acidification of ribose, galactose, glucose, fructose, mannose, mannitol, $N$-acetylglucosamine, arbutin, salicin, cellobiose, lactose, maltose, saccharose, trehalose, gentiobiose, methyl- $\beta$-D-glucopyranoside, L-arabinose, inulin, starch, and pullulan.

Type strain S69 has been deposited in the BCCM/LMG Culture Collection as strain LMG 13593. Strain $\mathrm{S} 69^{\mathrm{T}}$ was isolated from the intestine of a pig in 1984. Its characteristics are the same as those indicated above for the species. In addition, S69 $9^{\mathrm{T}}$ is positive for the following reactions which are variable in the species: $\alpha$-galactosidase, hippurate, alkaline phosphatase, glycyltryptophan arylamidase, sorbitol, raffinose, D-xylose, amygdalin, and melibiose. The $\mathrm{G}+\mathrm{C}$ content of LMG $13593^{\mathrm{T}}$ is $40 \mathrm{~mol} \%$.

Habitat. The two species described here are associated with pigs and appear to occur most frequently in pig vaginal fluids. However, the number $S$. hyovaginalis strains studied was very low, and $S$. thoraltensis was also found in pig intestines. Although the strains were isolated from postmortem specimens or from diseased animals, their possible involvement in pathological processes is not evident.

\section{REFERENCES}

1. Bentley, R. W., J. A. Leigh, and M. D. Collins. 1991. Intrageneric structure of Streptococcus based on comparative analysis of small-subunit rRNA sequences. Int. J. Syst. Bacteriol. 41:487-494.

2. De Ley, J. 1970. Reexamination of the association between melting point, buoyant density, and chemical base composition of deoxyribonucleic acid. J. Bacteriol. 101:738-754.
3. Descheemaeker, P., B. Pot, A. M. Ledeboer, T. Verrips, and K. Kersters. 1994. Comparison of the Lactococcus lactis differential medium (DCL) and SDS-PAGE of whole-cell protein extracts for the identification of lactococci to subspecies level. Syst. Appl. Bacteriol. 17:459-466.

4. Devereux, J., P. Haeberli, and O. Smithies. 1984. A comprehensive set of sequence analysis programs for the VAX. Nucleic Acids Res. 12:387-395.

5. Devriese, L. A., K. Ceyssens, J. Hommez, R. Kilpper-Bälz, and K. H. Scheifer. 1991. Characteristics of different Streptococcus suis ecovars and description of a simplified identification method. Vet. Microbiol. 26:141150.

6. Devriese, L. A., R. Kilpper-Bälz, and K. H. Schleifer. 1988. Streptococcus hyointestinalis sp. nov. from the gut of swine. Int. J. Syst. Bacteriol. 38:440441.

7. Devriese, L. A., G. N. Dutta, J. A. E. Farrow, A. Van de Kerckhove, and B. A. Phillips. 1983. Streptococcus cecorum, a new species isolated from chickens. Int. J. Syst. Bacteriol. 33:772-776.

8. Devriese, L. A., B. Pot, and M. D. Collins. 1993. Phenotypic identification of the genus Enterococcus and differentiation of phylogenetically distinct enterococcal species and species groups. J. Appl. Bacteriol. 75:399-408.

9. Devriese, L. A., and B. Pot. 1995. The genus Enterococcus, p. 327-367. In B. J. B. Wood and W. H. Holzapfel (ed.), The genera of lactic acid bacteria. Blackie, London, United Kingdom.

10. Elliott, J. A., M. D. Collins, N. E. Piggott, and R. R. Facklam. 1991. Differentiation of Lactococcus lactis and Lactococcus garvieae from humans by comparison of whole-cell protein patterns. J. Clin. Microbiol. 29:2731-2734.

11. Facklam, R. R., and M. D. Collins. 1989. Identification of Enterococcus species from human infections by a conventional test scheme. J. Clin. Microbiol. 27:731-734.

12. Facklam, R. R., and J. A. Elliott. 1995. Identification, classification, and clinical relevance of catalase-negative, Gram-positive cocci, excluding the streptococci and the enterococci. Clin. Microbiol. Rev. 8:479-495.

13. Felsenstein, J. 1989. PHYLIP-phylogeny inference package (version 3.2) Cladistics 5:164-166.

14. Jarvis, A. W., and J. M. Wolff. 1979. Grouping of lactic streptococci by gel electrophoresis of soluble cell extracts. Appl. Environ. Microbiol. 37:391398.

15. Laemmli, U. K. 1970. Cleavage of structural proteins during the assembly of the head of bacteriophage T4. Nature (London) 227:680-685.

16. Pot, B., L. A. Devriese, J. Hommez, K. Vandemeulebroecke, K. Kersters, and F. Haesebrouck. 1994. Characterization and identification of Vagococcus fluvialis strains isolated from domestic animals. J. Appl. Bacteriol. 77:362369.

17. Pot, B., L. A. Devriese, D. Ursi, P. Vandamme, F. Haesebrouck, and K. Kersters. 1996. Phenotypic identification and differentiation of Lactococcus strains isolated from animals. Syst. Appl. Microbiol. 19:213-222.

18. Pot, B., and D. Jansens. 1993. The potential role of a culture collection in the identification and maintenance of lactic acid bacteria, p. 81-87. In E. L. Foo, H. G. Griffin, R. Mollby, and C. G. Heden (ed.), The lactic acid bacteria. Proceedings of the First Lactic Computer Conference. Horizon Scientific Press, Norfolk, United Kingdom.

19. Pot, B., P. Vandamme, and K. Kersters. 1994. Analysis of electrophoretic whole organism protein fingerprints, p. 493-521. In M. Goodfellow and A. G. O'Donnell (ed.), Chemical methods in procaryotic systematics. J. Wiley and Sons, Chichester, United Kingdom.

20. Vandamme, P., B. Pot, E. Falsen, K. Kersters, and L. A. Devriese. 1996 Taxonomic study of Lancefield streptococcal groups C, G, and L (Streptococcus dysgalactiae) and proposal of $S$. dysgalactiae subsp. equisimilis subsp. nov. Int. J. Syst. Bacteriol. 46:774-781.

21. Vandamme, P., L. A. Devriese, B. Pot, K. Kersters, and P. Melin. 1997 Streptococcus difficile is a nonhemolytic group B, type Ib streptococcus. Int J. Syst. Bacteriol. 47:81-85.

22. Vauterin, L., and P. Vauterin. 1992. Computer-aided objective comparison of electrophoresis patterns for grouping and identification of microorganisms. Eur. Microbiol. 1:37-41.

23. Williams, A. M., and M. D. Collins. 1990 . Molecular taxonomic studies on Streptococcus uberis type I and II. Description of Streptococcus parauberis sp. nov. J. Appl. Bacteriol. 68:485-490. 